\title{
Composition of Cell Walls of Ageing Pseudomonas aeruginosa and Salmonella bethesda
}

\author{
By F. M. COLLINS \\ Department of Microbiology, University of Adelaide, Adelaide, South Australia
}

(Received 21 June 1963)

\begin{abstract}
SUMMARY
Anaerobic cultures of Pseudomonas aeruginosa died rapidly in the absence of nitrate and death was normally followed by extensive autolysis. A mutant which did not undergo extensive autolysis was isolated. Anaerobic cultures of Salmonella bethesda did not die or lyse even after prolonged incubation. The protein and lipid content of the parent $\boldsymbol{P}$. aeruginosa cell walls altered during ageing in contrast to $S$. bethesda walls which did not alter greatly as the organisms aged. The amino acid and amino sugar content of the three strains was determined. The diaminopimelic acid, glycine, alanine, glutamic acid, glucosamine, muramic acid and glucose content of the parent cell walls decreased by $50 \%$ as the organisms aged. The mutant strain of $\boldsymbol{P}$. aeruginosa and $\boldsymbol{S}$. bethesda walls showed no such change in ageing. Chemical changes similar to ageing could be produced in the cell walls of $\boldsymbol{P}$. aeruginosa by incubation with an 'autolysin' obtained from old cultures of the parent strain.
\end{abstract}

\section{INTRODUCTION}

Pseudomonas aeruginosa is a strict aerobe which can grow under anaerobic conditions when nitrate is added to the medium to act as an alternative to oxygen as hydrogen acceptor. Under these conditions rapid growth occurs until the exhaustion of the nitrate supply after which all growth ceases and the culture rapidly passes into the decline phase. Such cultures afford an opportunity to examine some of the changes which occur when non-proliferating organisms are held in an otherwise non-toxic environment.

Rapid death and extensive autolytic changes have previously been observed in anaerobically incubated cultures of Bacillus subtilis (Nomura \& Hosoda, 1956). Kaufmann \& Bauer (1958) noted rapid lysis of anaerobically incubated cultures of $B$. subtilis and isolated an autolytic enzyme from the medium. They suggested that this 'autolysin' was released in an active form by the organisms when the normal cellular respiration was inhibited. Lysis of several species of sporing bacilli has been examined in some detail (Strange, 1959) and a bacterial lysozyme has been shown to be involved in some instances (Richmond, 1959). The cell walls of Gram-negative bacilli are more complex in nature than those of the Gram-positive bacteria (Salton, 1958, 1960) and in general, lysozyme treatment of Gramnegative bacteria does not result in cell lysis except under special conditions (Warren, Gray \& Bartell, 1955; Repaske, 1958). A number of Gram-negative bacteria undergo autolysis on ageing, but for the most part little information is available on the mode of action of the enzymes involved. The similarities between 
the rapid death and autolysis observed in the anaerobic cultures of Pseudomonas aeruginosa and that reported for the corresponding anaerobically incubated Bacillus cultures suggested that a similar mechanism may be responsible for both phenomena. An 'autolysin' has been found in the culture medium of old $\boldsymbol{P}$. aeruginosa cultures and comparison of the composition of cell walls isolated from ageing organisms with that of young cell walls treated with the enzyme showed similar changes to occur in both.

\section{METHODS}

Organisms. Pseudomonas aeruginosa NCTC 6750 and Salmonella bethesda strain Md. 2 (kindly supplied by Dr N. Atkinson, University of Adelaide) were grown on nutrient agar slopes at $37^{\circ}$ for $\mathbf{2 4} \mathrm{hr}$ and stored at $4^{\circ}$. Subcultures were prepared from these slopes from time to time. A mutant strain of $\boldsymbol{P}$. aeruginosa, which was not subject to extensive autolysis on ageing, was isolated from an old broth culture of NCTC 6750 .

Medium. The growth medium contained the following nutrients: acid hydrolysate of casein (Oxoid Ltd., England), 5.0 g.; sodium nitrate, 5.0 g.; ammonium sulphate, $1.0 \mathrm{~g}$; ; magnesium sulphate, $0 \cdot 1 \mathrm{~g}$.; trace elements solution, $1.0 \mathrm{ml}$. (Meiklejohn, 1950); 0.067 M-2-amino-2-hydroxymethyl propane-1,3-diol (Tris) buffer ( $\mathrm{pH} \% \cdot 0$ ), 11 . The medium was autoclaved at $115^{\circ}$ for $15 \mathrm{~min}$.

Cultural conditions. The medium was dispensed in 11 . quantities in screw-capped serum bottles. Each bottle was inoculated with approximately $10^{7}$ viable bacteria. The air was removed with a vacuum pump after the insertion of a sterile hypodermic needle through the rubber wad. A positive gas pressure was introduced by returning sterile pure nitrogen into the bottle and removing the needle. The positive pressure ensured that air did not leak into the cultures during the prolonged incubation period. All cultures were incubated at $37^{\circ}$.

Counting methods. Viable bacteria were counted by the method of Miles \& Misra (1938). Total counts were made by the Williams (1952) method.

Quantitative analyses. Total-nitrogen, protein (Folin-Ciocalteau method and biuret method), total reducing sugar, total hexosamine and total phosphorus determinations were made by methods described by Kabat \& Mayer (1961). Nitrate was estimated as previously described (Collins, 1956).

Individual sugars were identified chromatographically after hydrolysis of the walls with $2 \mathrm{~N}$-sulphuric acid at $100^{\circ}$ for $2 \mathrm{hr}$. The descending chromatograms were run in ethyl acetate + acetic acid + water $\left(3+1+3\right.$ by vol.) for $18 \mathrm{hr}$ at $20^{\circ}$. The papers were sprayed with aniline phthalate reagent (Cramer, 1954) and the sugar content of each spot estimated by the method of Baar (1954). Muramic acid was estimated by the method described by Strange \& Kent (1959).

Amino acids were identified, after hydrolysis of cell walls with $6 \mathrm{~N}-\mathrm{HCl}$ at $105^{\circ}$ for $18 \mathrm{hr}$, by two-dimensional chromatography as described by Salton (1953). The intensities of the colours obtained with ninhydrin were compared with those for standard spots of known amino acids developed under identical conditions.

Lipids were estimated by the method described by Salton (1953).

Preparation of cell walls. Organisms were washed twice in saline and once in distilled water and suspended in cold distilled water at a concentration equivalent to $20 \mathrm{mg}$. dry wt. $/ \mathrm{ml}$. The cells were then exposed for $15 \mathrm{~min}$. to sonic vibration in 
a Raytheon disintegrator with an output of $50 \mathrm{~W}$. at $9 \mathrm{kc} . / \mathrm{sec}$., the suspension being kept at $0^{\circ}$ throughout the experiment. The cell walls were washed by the method of Munoz, Ribi \& Larsen (1959) and their purity checked by the examination of palladium shadowed preparations with a Philips model EM 100 electron microscope. The cell walls were suspended in distilled water and stored at $-20^{\circ}$ until required.

Concentration of autolysin from old cultures of Pseudomonas aeruginosa. Eight-day anaerobic cultures of $P$. aeruginosa were freed from whole cells by centrifugation at $8000 \mathrm{rev} . / \mathrm{min}$. for $30 \mathrm{~min}$. The supernatant fluid was adjusted to $\mathrm{pH} 7 \cdot 0$ with $\mathrm{N}$-acetic acid. Solid ammonium sulphate was slowly added in the cold to a final concentration of $3 \mathrm{M}$. The precipitate which formed was spun down, washed with $3 \mathrm{M}$-ammonium sulphate and re-dissolved in $0.067 \mathrm{M}$-Tris buffer $(\mathrm{pH} 7 \cdot 0)$. The preparation was dialysed against $0.067 \mathrm{M}$-Tris buffer $(\mathrm{pH} 7 \cdot 0)$. The precipitate in the dialysis sac was spun off and discarded. Nucleic acids were removed with protamine sulphate (Korkes, del Campillo \& Ochoa, 1950). The autolysin was re-precipitated with $3 \mathrm{M}$-ammonium sulphate and dialysed against $0 \cdot 067 \mathrm{M}$-Tris buffer $(\mathrm{pH} \mathrm{7 \cdot 0)}$. After centrifugation the clear supernatant fluid was assayed for protein and diluted with buffer until it contained $5 \mathrm{mg}$. protein $/ \mathrm{ml}$. Three $\mathrm{ml}$. of the enzyme preparation was added to the equivalent of $200 \mathrm{mg}$. dry wt. $24 \mathrm{hr} P$. aeruginosa NCTC 6750 cell walls suspended in $5 \mathrm{ml}$. of $0.01 \mathrm{M}$-Tris buffer $(\mathrm{pH} 8.0)$ and the volume made up to $10 \mathrm{ml}$. with Tris buffer $\left(\mathrm{pH} \mathrm{8.0)}\right.$ ). The preparation was incubated at $45^{\circ}$ for $20 \mathrm{hr}$ and the cell walls were spun down at $20,000 \mathrm{~g}$ for $30 \mathrm{~min}$. The walls were washed twice in cold $0.067 \mathrm{~m}$-Tris buffer $(\mathrm{pH} 7 \cdot 0)$ and stored in distilled water at $-20^{\circ}$ until required for assay.

\section{RESULTS}

The growth of Pseudomonas aeruginosa and Salmonella bethesda in anaerobic cultures

Both the parent and the mutant strain of $P$ seudomonas aeruginosa grew vigorously in the anaerobic cultures. A maximum viable population of $3-5 \times 10^{9}$ organisms $/ \mathrm{ml}$. was maintained until exhaustion of the nitrate supply (shown by an arrow in Fig. 1) whereupon a rapid and extensive decline in viable count was regularly observed (Fig. 1). Following the decrease in viable count the $P$. aeruginosa NCTC 6750 culture showed $40-50 \%$ lysis on ageing, whereas the mutant showed very little lysis (5-10\%; see Fig. 1). The maximum viable population of Salmonella bethesda remained constant at $4-5 \times 10^{8}$ organisms $/ \mathrm{ml}$. throughout the experiment and the culture did not undergo any observable autolytic changes during ageing. The extensive lysis observed in the older cultures of $P$. aeruginosa NCTC 6750 suggested the presence in those cultures of an autolytic enzyme and so lysis experiments with young washed suspensions in the presence of cell-free culture filtrates were attempted. Preliminary experiments showed that some lytic activity was associated with the fluid of old cultures; to obtain significant results it was necessary to first concentrate the 'autolysin' by ammonium sulphate precipitation.

Incubation of young resting cell suspensions of Pseudomonas aeruginosa NCTC 6750 with the crude autolysin concentrate resulted in the lysis of $\mathbf{4 0 - 5 0 \%}$ of the organisms in 10-15 min. Total counts confirmed that after $60 \mathrm{~min}$. only $20 \%$ of the original organisms were still intact. Control suspensions which were incubated with heated autolysin $\left(100^{\circ}\right.$ for $10 \mathrm{~min}$.) showed little or no lysis during this time (Fig. 2). The addition of ethylenediaminetetraacetic acid (EDTA) to the test mixture greatly 
increased the rate of lysis of the parent Pseudomonad and the mutant so that 60-70\% lysis was observed within 2-4 min. Control suspensions (containing EDTA only) decreased by $10 \%$ over the $10 \mathrm{~min}$. period. Ammonium sulphate precipitation of cell-free culture filtrates of aged mutant broth cultures yielded preparations with little or no lytic activity for parent or mutant Pseudomonads either in the presence or absence of EDTA. Lysis presumably resulted from the hydrolysis of the cell wall by the autolysin and attempts were, therefore, made to determine the possible substrates of the enzyme by making chemical analyses of the cell walls of the ageing bacteria.

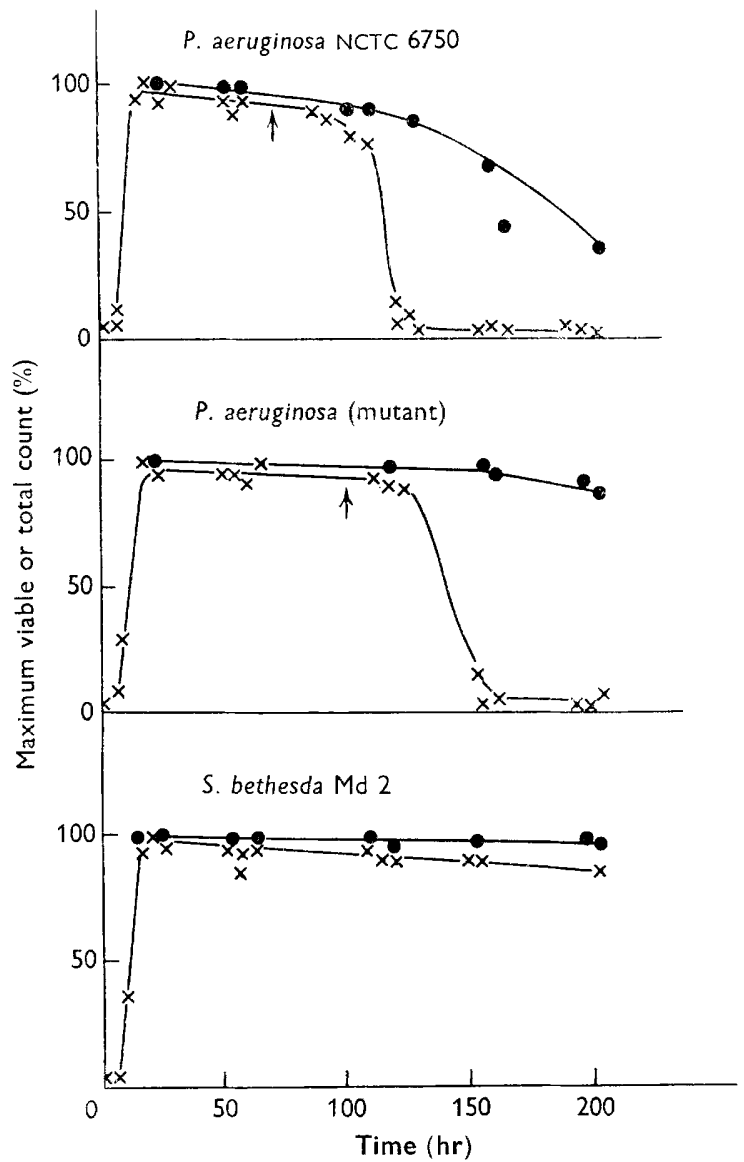

Fig. 1. Growth curves of Pseudomonas aeruginosa NCTC 6750, P. aeruginosa (mutant) and Salmonella bethesda in casein hydrolysate medium incubated anaerobically at $37^{\circ}$. The arrow indicates the time the nitrate supply became exhausted. $\times-\times=$ viable count; - $=$ total count. Nitrate was still present in the $S$. bethesda culture at $192 \mathrm{hr}$.

\section{Composition of ageing bacterial cell walls}

The details of the balance sheets for washed cell walls of the three organisms are set out in Tables 1 and 4 .

Total nitrogen and protein. The total-N content of the walls of the three organisms accounted for $8-11 \%$ of the dry weight and showed very little change with age. 
The cell walls of young Pseudomonas aeruginosa NCTC 6750 cultures contained 50-60 mg. protein/100 mg. dry wt. wall and this rose to almost $70 \mathrm{mg}$. in old organisms. By contrast, the cell walls of the Pseudomonas mutant together with

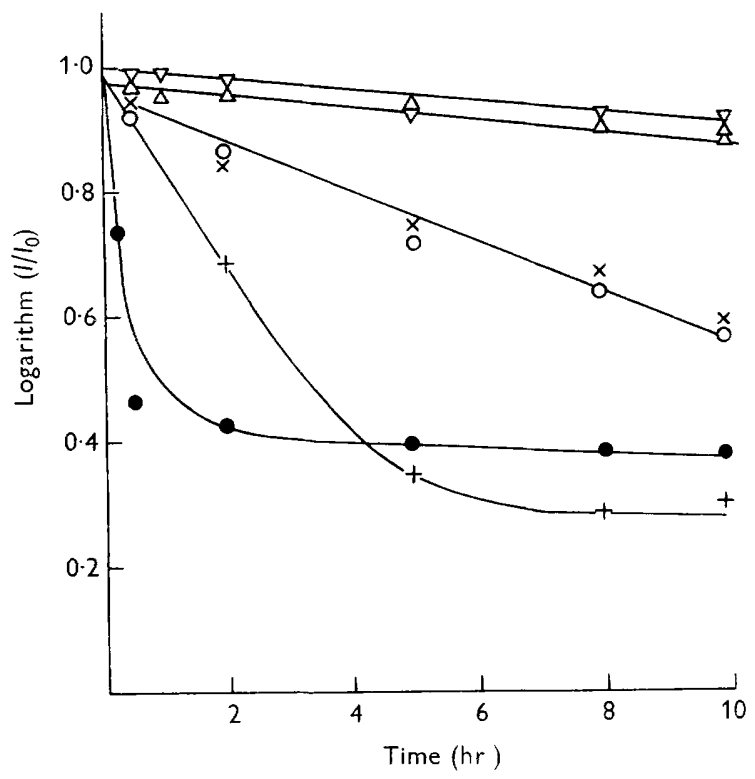

Fig. 2. Lysis of resting suspensions of Pseudomonas aeruginosa NCTC 6750 and $P$. aeruginosa (mutant) by crude autolysin in the presence of $0.01 \mathrm{~m}$-'Tris (pH 8.0) and $100 \mu \mathrm{g}$. ethylenediaminetetraacetic acid (EDTA)/ml. - - $P$. aeruginos $a$ NCTC $6750+$ autolysin + EDTA; $\mathrm{O}-\mathrm{O}, P$. aeruginosa NCTC $6750+$ autolysin;,$+-+ P$. aeruginosa mutant + autolysin + EDTA; $\times-\times, P$ aeruginosa mutant + autolysin $; \triangle-\triangle, P$. aeruginosa + EDTA; $\nabla-\nabla, P$. aeruginosa control.

Table 1. Composition of cell walls of ageing bacteria

\begin{tabular}{|c|c|c|c|c|c|c|c|}
\hline \multirow[b]{2}{*}{$\begin{array}{l}\text { Age } \\
\text { (hr) }\end{array}$} & & \multirow[b]{2}{*}{ Total-N } & \multirow{2}{*}{\multicolumn{2}{|c|}{$\begin{array}{cc} & \begin{array}{c}\text { Total } \\
\text { reducing }\end{array} \\
\text { Protein* } & \text { sugar } \\
\text { (mg./100 mg. dry }\end{array}$}} & \multirow[b]{2}{*}{$\begin{array}{l}\text { Total-P } \\
\text { wt. cell }\end{array}$} & \multicolumn{2}{|c|}{ Lipid } \\
\hline & & & & & & $\begin{array}{l}\text { Free } \\
\text { lls) }\end{array}$ & Tota \\
\hline 24 & \multirow{4}{*}{$\begin{array}{l}\text { Pseudomonas } \\
\text { aeruginosa } \\
\text { NCTC } 6750\end{array}$} & $8 \cdot 4$ & 54 & 8.0 & 1.7 & $5 \cdot 2$ & 15 \\
\hline 48 & & $8 \cdot 4$ & 50 & - & $1 \cdot 1$ & - & 15 \\
\hline 96 & & 8.8 & 61 & - & $1 \cdot 4$ & - & 12 \\
\hline 192 & & $8 \cdot 7$ & 64 & $6 \cdot 1$ & $1 \cdot 6$ & $5 \cdot 4$ & 4 \\
\hline 24 & Enzyme treated $\uparrow$ & - & 63 & $6 \cdot 0$ & - & $7 \cdot 6$ & 10 \\
\hline 24 & \multirow{4}{*}{$\begin{array}{c}P . \text { aeruginosa } \\
\text { (mutant) }\end{array}$} & $10 \cdot 1$ & 70 & $12 \cdot 1$ & $1 \cdot 6$ & $6 \cdot 3$ & 16 \\
\hline 96 & & $10 \cdot 5$ & 72 & - & $1 \cdot 4$ & - & 14 \\
\hline 120 & & $10 \cdot 0$ & 69 & - & 1.0 & - & 11 \\
\hline 192 & & $10 \cdot 9$ & 70 & $13 \cdot 5$ & $1 \cdot 0$ & $5 \cdot 8$ & 13 \\
\hline 48 & \multirow{3}{*}{ Salmonella bethesda } & $8 \cdot 0$ & 77 & $18 \cdot 5$ & $1 \cdot 7$ & $8 \cdot 7$ & 12 \\
\hline 96 & & $9 \cdot 0$ & 63 & - & $1 \cdot 7$ & $6 \cdot 0$ & 11 \\
\hline 192 & & $9 \cdot 0$ & 63 & $15 \cdot 4$ & $1 \cdot 6$ & $7 \cdot 2$ & 10 \\
\hline
\end{tabular}

* Average of Folin-Ciocalteau and biuret determinations.

$\dagger 24 \mathrm{hr} P$. aeruginosa NCTC 6750 cell walls incubated at $45^{\circ}$ for $20 \mathrm{hr}$ in $0 \cdot 01 \mathrm{~m}$-Tris buffer (pH 8-0) with the enzyme preparation. 
those of Salmonella bethesda, contained $65-70 \mathrm{mg}$. protein/100 mg. dry wt. wall irrespective of the age of the cells (Table 1).

Amino acids. The amino acid composition of the cell walls altered significantly as the cells aged (Table 2). Although the over-all recovery of amino acids increased with age, considerable decreases were observed in the amounts of diaminopimelic acid (DAP), alanine, glutamic acid and glycine present in the older cell walls of the parent strain. The amino acid composition of the cell walls of young mutant Pseudomonads closely resembled that of the parent but there was no corresponding decrease in the DAP, alanine, glutamic acid or glycine content as the organisms aged (Table 3). The amino acid composition of the Salmonella bethesda cell walls differed quantitatively but not qualitatively from that of the Pseudomonas aeruginosa preparations.

Table 2. Amino acid composition of Pseudomonas aeruginosa NCTO 6750 cell walls

\begin{tabular}{|c|c|c|c|c|}
\hline \multicolumn{4}{|c|}{ Age of cell walls (hr) } & \multirow{3}{*}{$\begin{array}{c}\text { Enzyme } \\
\text { treated* } \\
24\end{array}$} \\
\hline 24 & 40 & 88 & 192 & \\
\hline \multicolumn{4}{|c|}{ (mg./100 mg. dry wt. cell walls) } & \\
\hline $6 \cdot 0$ & $7 \cdot 8$ & $9 \cdot 0$ & $9 \cdot 5$ & $6 \cdot 3$ \\
\hline $2 \cdot 2$ & $2 \cdot 9$ & $3 \cdot 5$ & $3 \cdot 5$ & $2 \cdot 4$ \\
\hline $3 \cdot 0$ & $2 \cdot 5$ & $2 \cdot 6$ & $2 \cdot 0$ & $1 \cdot 7$ \\
\hline $\mathbf{3 \cdot 3}$ & $2 \cdot 6$ & $3 \cdot 4$ & $2 \cdot 8$ & $2 \cdot 4$ \\
\hline 0.9 & $0 \cdot 6$ & $0 \cdot 6$ & $0 \cdot 9$ & $0 \cdot 9$ \\
\hline $1 \cdot 1$ & $0 \cdot 8$ & 0.9 & $1 \cdot 1$ & $0 \cdot 8$ \\
\hline $7 \cdot 2$ & $7 \cdot 5$ & $4 \cdot 2$ & $\mathbf{3} \cdot \mathbf{3}$ & $3 \cdot 1$ \\
\hline $11 \cdot 0$ & $11 \cdot 4$ & $6 \cdot 3$ & $6 \cdot 6$ & $5 \cdot 6$ \\
\hline $5 \cdot 0$ & - & $4 \cdot 0$ & $3 \cdot 4$ & $4 \cdot 1$ \\
\hline $6 \cdot 6$ & $5 \cdot 7$ & $4 \cdot 7$ & $\mathbf{3} \cdot \mathbf{2}$ & $4 \cdot 6$ \\
\hline $14 \cdot 4$ & $11 \cdot 6$ & $9 \cdot 6$ & $11 \cdot 4$ & $10 \cdot 9$ \\
\hline $2 \cdot 8$ & $3 \cdot 0$ & $1 \cdot 7$ & $1 \cdot 2$ & $0 \cdot 9$ \\
\hline
\end{tabular}

Table 3. Amino acid composition of Pseudomonas aeruginosa (mutant strain) and Salmonella bethesda cell walls

Phenylalanine
Leucine and isoleucine
Valine
Tyrosine
Arginine
Lysine
Alanine
Glycine
Serine
Glutamic acid
Aspartic acid
Diaminopimelic acid

Amino acid

ucine 
Carbohydrate. The details of the total reducing sugar content of the three cell wall preparations are given in Table 4. Pseudomonas aeruginosa NCTC 6750 showed a decrease in total reducing sugar content with ageing whilst the cell walls of the mutant did not show any ageing effect. However, the cell walls of the mutant contained more reducing sugar residues than did the walls of the parent strain. The Salmonella bethesda cell walls contained $18.5 \mathrm{mg}$. reducing sugar/100 $\mathrm{mg}$. wall and this decreased slightly with ageing ('Table 4). The walls of all three organisms contained 1 $15-2 \cdot 0 \mathrm{mg}$. of amino sugar $/ 100 \mathrm{mg}$. wall, of which about half was muramic acid (Table 4). The amino sugar content of $P$. aeruginosa NCTC 6750 cell walls decreased by $50 \%$ as the organisms aged. Little change in the amino sugar content of the other two organisms was noted. Chromatographic identification of the individual cell wall sugars and amino sugars disclosed the presence of glucose, mannose, rhamnose, glucosamine and muramic acid (Table 4). The cell walls of $P$. aeruginosa NCTC 6750 contained approximately equimolar amounts of glucose and rhamnose. The glucose content of the walls decreased by $60 \%$ as the organisms aged, whereas the rhamnose and the mannose content changed very little (Table 4). The glucose and mannose content of the cell walls of the mutant was almost double that of the parent and this offers an explanation for the higher reducing sugar content observed with the cell walls of the mutant. The sugar content of the $S$. bethesda cell wall was quantitatively quite distinct from both Pseudomonads and there was no detectable alteration in sugar content on ageing.

Table 4. Carbohydrate and amino sugar composition of cell walls of ageing bacteria

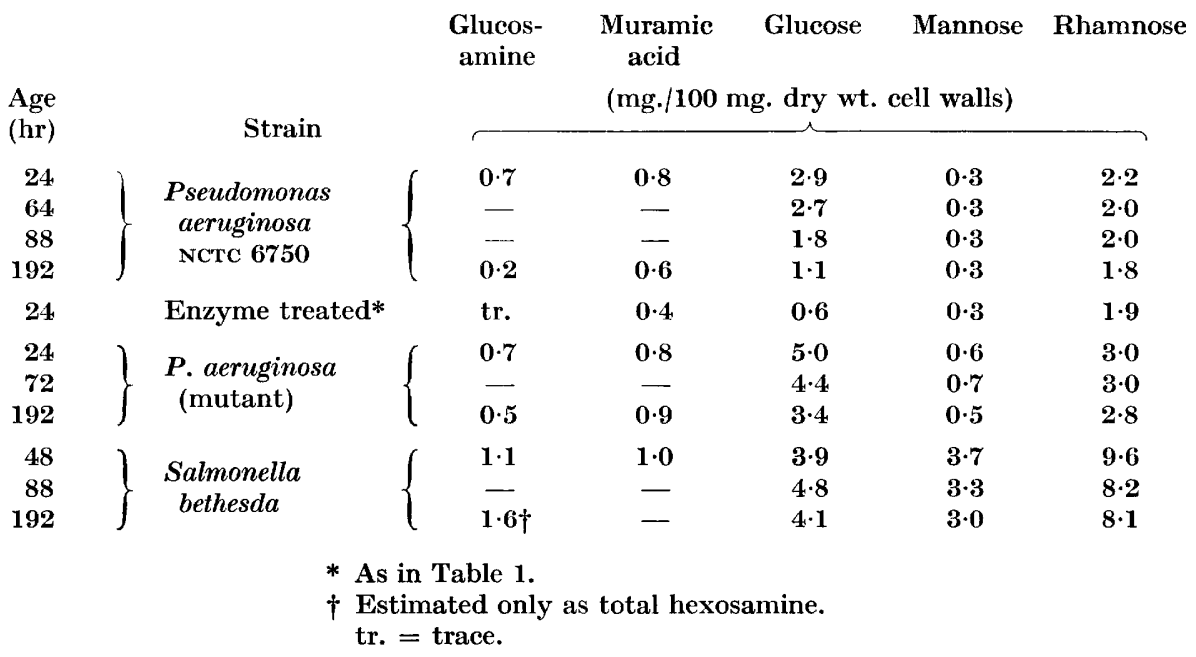

Lipid and total phosphorus. The phosphorus content of the cell walls of the three strains varied from 1 to $2 \mathrm{mg} . / 100 \mathrm{mg}$. wall and there was no change on ageing. The free lipid content varied between $5 \cdot 2$ and $8 \cdot 7 \mathrm{mg} . / 100 \mathrm{mg}$. wall and did not alter with ageing. However, the total lipid content of the parent pseudomonad walls decreased by almost $25 \%$ (Table 1). The lipid content of the walls of the mutant and of Salmonella bethesda showed very little change on ageing. The total recovery 
of wall material varied from 80 to $100 \%$. The high recoveries for the mutant walls were mainly due to the unexplained $15-20 \mathrm{mg} . / 100 \mathrm{mg}$. wall increase in the protein content of these walls. The incomplete recoveries for Pseudomonas aeruginosa NCTC 6750 and $S$. bethesda suggest that there may be other undetected minor components in these walls.

\section{Autolysis of washed Pseudomonas aeruginosa cell walls}

Incubation of young Pseudomonas aeruginosa cell walls with the crude autolysin obtained from old cultures resulted in a change in opacity of 15-20\% in $18 \mathrm{hr}$. Chemical assays carried out on the hydrolysed cell walls disclosed changes in composition similar to those recorded above for aged cell-wall preparations. The protein content increased somewhat but the total reducing sugar was not apparently affected (Table 1). However, chromatographic examination of the cell-wall hydrolysates disclosed that the amino acids DAP, alanine, glycine and glutamic acid decreased by $\mathbf{5 0} \%$ (Table 2 ). Similarly, the glucosamine and muramic acid content of the walls decreased sharply (Table 4). The total lipid content of the walls also decreased considerably (Table 1). The composition of a control cell wall suspension treated with boiled autolysin resembled, within experimental error, the initial $24 \mathrm{hr}$ old preparation recorded in Table 1.

\section{DISCUSSION}

The observed lysis of the anaerobically incubated Pseudomonas aeruginosa NCTC 6750 was due to the presence of an extracellular autolysin. Cultures of the mutant strain and Salmonella bethesda did not produce detectable amounts of autolysin in ageing cultures, although the mutant was still susceptible to lysis. Thus the mutation appeared to involve the loss of ability to produce an extracellular autolysin, rather than the formation of a lysis-resistant cell wall. The mutant cells were still strictly aerobic and were subject to a rapid and extensive degree of killing when incubated under anaerobic conditions. The absence of subsequent lysis of these cells suggests that the lethal and lytic processes observed in cultures of $P$. aeruginosa NCTC 6750 are distinct and not directly inter-related.

The gross chemical composition of the cell walls of the three strains of bacteria underwent a number of changes as the cultures passed through their growth phases. The most interesting alterations occurred in the amino acid and amino sugar content of the ageing cell walls of the parent strain. The over-all amino acid content of the walls increased slightly as the cells aged. This was to be expected from the observed increases in total protein. The coincidence of the sharp decline in the DAP, alanine, glycine and glutamic acid content of the walls of the parent strain with the onset of autolysis suggested a causal relationship between the two phenomena. Significantly, the cell walls of neither the mutant strain nor Salmonella bethesda showed any comparable decrease in these amino acids. In view of the known importance of these amino acids in the cell wall mucopeptides of other Gram-negative bacteria (Salton, 1958, 1960; Brown, 1958) it seems reasonable to presume that the autolysin present in the cultures of the parent strain removed part of the rigid mucopeptide layer from the Pseudomonas aeruginosa cell walls so that cell lysis resulted. The removal of at least $50 \%$ of the muramic acid and glucosamine from the aged 
$P$. aeruginosa NCTC 6750 cell walls was taken as confirmation that the entire mucopeptide moiety was affected. However, the Pseudomonas autolysin was not a simple bacterial lysozyme since the crude autolysin preparation was unable to lyse Micrococcus lysodeikticus suspensions.

The removal of complex lipid from the cell walls of the parent strain during ageing suggested the presence of an esterase in the autolysin. Sierra (1957) demonstrated the presence of several esterases in Pseudomonas aeruginosa cells and noted a correlation between their presence in the culture medium and the subsequent induction of cellular lysis. In the present study, both the whole organisms and the autolysin concentrate were found to have lecithinase activity when tested against serum lecithin. The loss of lipid from the ageing cell walls of the parent but not the mutant organism suggested that lysis of the cell was initiated only after some lipid complex in the wall had been removed. This was confirmed by the increased autolysis of $\boldsymbol{P}$. aeruginosa following treatment of the cells with acetone or Teepol. Increased autolysis following treatment of cells with lipid solvents has previously been observed by Warren et al. (1955) and others. Presumably the removal of a lipid moiety exposed the mucopeptide layer which could then be attacked by other enzymes present in the autolysin. Thus it seems likely that the $\boldsymbol{P}$. aeruginosa autolysin consists of a mixture of at least two enzymes and is distinct from the autolysins produced by the Gram-positive bacteria. Further purification of the autolysins of this and other Gram-negative bacteria would, therefore, be useful and should reveal whether or not the autolysin of $\boldsymbol{P}$. aeruginosa is typical of the enzymes produced by other Gram-negative micro-organisms.

The author wishes to thank Professor D. Rowley for his help and advice during this study. I am indebted to Mr H. Konczalla (Physics Department, University of Adelaide) for taking the electron micrographs and to Mrs A. McAskill for technical assistance.

\section{REFERENCES}

BAAR, S. (1954). Quantitative estimation of glucose by paper partition chromatography. Biochem. J. 58, 175.

Brown, A. D. (1958). An effect of drying the isolated cell walls of Streptococcus faecalis and a Pseudomonas species. Biochim. biophys. Acta, 28, 445.

Collins, F. M. (1956). Bacterial denitrification in shaken cultures. Enzymologia, 17, 291. Cramer, F. (1954). Paper Chromatography, 2nd ed. London: Macmillan and Co.

Kabat, E. A. \& MaYer, M. M. (1961). Experimental Immunochemistry, 2nd ed. Springfield, Ill.: Charles C. Thomas.

Kaufmann, W. \& Bauer, K. (1958). Some studies on the mechanism of the 'Anaerobic autolysis' of Bacillus subtilis. J. gen. Microbiol. 18, xi.

Korkes, S., del Campillo, A. \& Ochoa, S. (1950). Biosynthesis of dicarboxylic acids by carbon dioxide fixation. IV. Isolation and properties of an adaptive 'Malic' enzyme from Lactobacillus arabinosus. J. biol. Chem. 187, 891.

Meiklejohn, J. (1950). The isolation of Nitrosomonas europaea in pure culture. J. gen. Microbiol. 4, 185.

Miles, A. A. \& Misra, S. A. (1938). The estimation of the bactericidal power of the blood. J. Hyg., Camb. 38, 732.

Munoz, J., Ribi, E. \& Larsen, C. L. (1959). Antigens of Bordetella pertussis. 1. Activities of cell walls and protoplasm. J. Immunol. 83, 496.

Nomura, M. \& Hosoda, J. (1956). Nature of the primary action of the autolysin of Bacillus subtilis. J. Bact. 72, 573. 
Repaske, R. (1958). Lysis of Gram-negative bacteria by lysozyme. Biochim. biophys. Acta, 22, 189.

Richmond, M. H. (1959). Formation of a lytic enzyme by a strain of Bacillus subtilis. Biochim. biophys. Acta, 33, 78.

Salton, M. R. J. (1953). Studies of the bacterial cell wall. IV. The composition of the cell walls of some Gram-positive and Gram-negative bacteria. Biochim. biophys. Acta, $10,512$.

Salton, M. R. J. (1958). The lysis of micro-organisms by lysozyme and related enzymes. J. gen. Microbiol. 18, 481.

Salton, M. R. J. (1960). The Bacteria. Ed. by I. C. Gunsalus and R. Y. Stanier, vol. 1, p. 97. London and New York: Academic Press.

Srerra, G. (1957). Studies on bacterial esterases. I. Differentiation of a lipase and two ali-esterases during the growth of Pseudomonas aeruginosa and some observations on growth and esterase inhibition. Antonie van Leeuwenhoek, 23, 241.

Strange, R. E. (1959). Cell wall lysis and the release of peptides in Bacillus species. Bact. Rev. 23, 1.

Strange, R. E. \& Kent, L. H. (1959). 'The isolation, characterisation and chemical synthesis of muramic acid. Biochem. J. 71, 333.

Warren, G. H., Gray, J. \& Bartell, P. (1955). The lysis of Pseudomonas aeruginosa by lysozyme. J. Bact. 70, 614 .

Williams, R. E. O. (1952). Investigations into a method for counting the total number of bacteria in a suspension. J. gen. Microbiol. 7, 89. 